\title{
Penerapan Model Pembelajaran Inquiry Berbantuan Video Pembelajaran Dan Tutorial Untuk Meningkatkan Hasil Belajar Fisika Pada Siswa Kelas X SMA Negeri 5 Palu
}

\author{
Subhan Jaelani, Darsikin, dan Sahrul Saehana \\ subhanjae014@gmail.com \\ Program Studi Pendidikan Fisika FKIP Universitas Tadulako \\ Jl. Soekarno Hatta Km. 9 Kampus Bumi Tadulako Tondo Palu - Sulawesi Tengah
}

\begin{abstract}
Abstrak - Penelitian ini bertujuan untuk meningkatkan hasil belajar fisika kelas X MIPA SMA Negeri 5 Palu. Subjek dari penelitian ini adalah kelas X MIPA 2 SMA Negeri 5 Palu. Kelas X MIPA 2 ini memiliki 33 siswa yang terdiri 8 siswa laki-laki dan 25 siswa perempuan. Penelitian Tindakan kelas ini mengikuti rancangan model John Elliot (Sunendar, Tatang : 2008) yang dilakukan dalam dua siklus, dengan tiap siklus melalui 4 tahap, yaitu : (1) Perencanaan, (2) Pelaksanaan, (3) Observasi, dan (4) Refleksi. Berdasarkan hasil analisis data, pada siklus I diperoleh hasil belajar dengan ketuntasan klasikal sebesar 72,73\% dan pada siklus II diperoleh hasil belajar dengan ketuntasan klasikal sebesar 81,81 \%. Pada siklus I, observasi aktivitas guru dan siswa berada pada kategori baik dan pada siklus 2, observasi aktivitas guru dan siswa berada pada kategori sangat baik. Berdasarkan indikator maka dapat disimpulkan bahwa penerapan model pembelajaran berbantuan video pembelajaran dan tutorial dapat meningkatkan hasil belajar fisika siswa.
\end{abstract}

Kata Kunci: hasil belajar fisika, model pembelajaran inquiry. berbantuan Video Pembelajaran dan tutorial

\section{PENDAHULUAN}

Dalam pelajaran fisika, seringkali siswa sering menganggap pelajaran fisika itu sulit. Pada saat wawancara dilakukan hampir semua siswa menjawab bahwa pelajaran fisika itu lumayan sulit, sehingga membuat mereka bosan ketika belajar fisika dengan bukti ratarata nilai fisika mereka rendah. Berdasarkan hasil observasi yang dilakukan di SMAN 5 Palu, peneliti melihat siswa yang dijadikan Subjek penelitian (Siswa kelas X MIPA 2), kebanyakan siswa yang kurang perhatiannya ke pelajaran fisika. Perhatian mereka terhadap pelajaran khususnya pelajaran fisika masih rendah.

Pada guru memberikan materi di kelas, siswa ada yang tidak memperhatikan guru, masih ada siswa yang berbicara dengan temannya, ada juga siswa yang kurang fokus, apabila ditanya oleh guru, ada yang tidak bisa menjawab, dan ada sebagian siswa yang merasa bosan pada saat guru menjelaskan.

Dari uraian nilai siswa, maka nilai total ratarata harian fisika siswa kelas X MIPA 2 yaitu $73,3 \%$ dan belum mencapai indikator ketuntasan klasikal (menurut Depdiknas, tahun 2001 yang mengatakan "suatu kelas dinyatakan tuntas belajar klasikal jika rata-rata $80 \%$ siswa telah tuntas secara individual"). Hal ini juga merupakan landasan peneliti untuk mengambil model pembelajaran Inquiry berbantuan Video Pembelajaran dan Tutorial agar bisa meningkatkan hasil belajar siswa pada kelas X MIPA 2 SMA Negeri 5 Palu.

Hal ini terjadi karena Pada saat peneliti melakukan wawancara kepada guru fisika SMAN 5 Palu terkait metode pembelajaran yang diberikan pada saat mengajar, guru hanya memberikan metode ceramah dan pemberian tugas dalam memberi pelajaran fisika, guru jarang memberikan materi dengan bantuan multimedia seperti pemberian materi dengan menggunakan power point, video pembelajaran dan sebagainya. Hal ini disebabkan karena guru fisika itu belum bisa menemukan seni dalam mengajarkan pelajaran fisika, guru hanya di depan kelas sebagai pembicara dengan memberikan metode ceramah,lalu tanya jawab serta diskusi. Tidak adanya inovasi-inovasi yang dibuat oleh guru untuk memberi rangsangan peningkatan belajar fisika terhadap siswanya, menyebabkan nilai rata-rata fisika siswa kelas X MIPA 2 rendah.

Karena dengan model pembelajaran Inquiry, siswa dapat lebih aktif dan ikut terlibat didalam proses pembelajaran, karena manfaat yang utama dari Inquiry adalah mencari dan memecahkan masalah [1-2]. Dan akan lebih efektif lagi jika ditambahkan dengan video pembelajaran dan tutorial. 
Video pembelajaran diberikan kepada siswa untuk bisa merangsang pemahaman siswa dan menambah rasa ingin tahu siswa untuk bisa menggali dan mencari suatu permasalahan yang ada divideo pembelajaran.

Dan untuk memecahkan permasalahan yang sudah ditampilkan pada video pembelajaran, maka dibutuhkan video tutorial yang berisikan intsruksi untuk melakukan suatu eksperimen/praktikum agar permasalahan itu bisa diselesaikan oleh siswa.

Penggunaan model pembelajaran Inquiry berbantuan video pembelajaran dan tutorial dapat meningkatkan hasil belajar fisika siswa.

Tujuan dari penelitian ini adalah "untuk mengetahui apakah dengan model pembelajaran inquiri berbantuan Video Pembelajaran dan Tutorial dapat meningkatkan hasil belajar fisika pada siswa kelas X SMA Negeri 5 Palu".

\section{METODE PENELITIAN}

Penelitian ini merupakan penelitian tindakan kelas, yang mengacu pada desain Arikunto dkk yang meliputi empat tahap yaitu: perencanaan (2) pelaksanaan tindakan (3) observasi dan (4) refleksi. Adapun tahapan pelaksanaan tindakan yang dimaksud seperti pada Gambar 1.

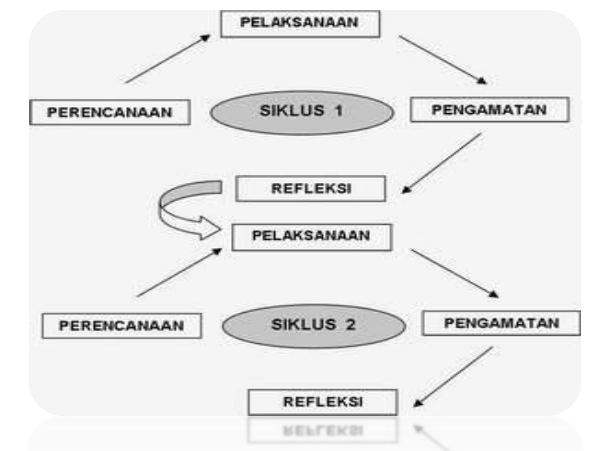

Gbr 1 Model PTK (Penelitian Tindaka Kelas)

Menurut John Elliot (Sunendar, Tatang : 2008) [3]

Penelitian ini dilaksanakan di SMA Negeri 5 Palu yang dimulai pada tanggal 26 Januari sampai dengan 8 Maret 2017. Subjek penelitian ini adalah kelas $X$ MIPA 2 dengan jumlah siswa terdiri atas 8 orang laki-laki dan 25 orang perempuan.

Jenis data yang dikumpulkan dalam penelitian ini adalah (1) data kualitatif yaitu data yang diperoleh dari data hasil observasi kegiatan guru dan kegiatan siswa dalam proses kegiatan belajar mengajar, data afektif, serta psikomotor. (2) data kuantitatif yaitu data yang diperoleh dari tes hasil belajar.

\section{HASIL DAN PEMBAHASAN}

Kegiatan observasi aktivitas siswa dan guru dilakukan untuk melihat keaktifan siswa dan guru selama proses pembelajaran berlangsung. Pada siklus I, Aktivitas guru pada pertemuan 1 berada pada kategori baik dan pertemuan 2 berada pada kategori sangat baik. Sedangkan aktivitas siswa pada pertemuan 1 berada pada kategori baik dan pertemuan 2 berada pada kategori sangat baik.

Sedangkan pada siklus II, Aktivitas guru pada pertemuan 1 berada pada kategori sangat baik dan pertemuan 2 berada pada kategori sangat baik. Sedangkan aktivitas siswa pada pertemuan 1 berada pada kategori sangat baik dan pertemuan 2 berada pada kategori sangat baik.

Hasil belajar siswa pada siklus 1 dengan ketuntasan klasikal sebesar $72,73 \%$ dan pada siklus II dengan ketuntasan klasikal $81,51 \%$, dapat dilihat pada tabel 1

TABEL 1. HASIL ANALISIS TES AKHIR TINDAKAN SIKLUS

\begin{tabular}{|c|c|c|c|}
\hline \multirow[b]{2}{*}{ No } & \multirow[b]{2}{*}{ Aspek Perolehan } & \multicolumn{2}{|c|}{ Hasil } \\
\hline & & Siklus I & Siklus 2 \\
\hline 1 & Skor tertinggi & 24 orang & 27 orang \\
\hline 2 & Skor terendah & 9 orang & 6 orang \\
\hline 3 & $\begin{array}{l}\text { Banyaknya siswa yang } \\
\text { tuntas }\end{array}$ & 24 orang & 27 orang \\
\hline 4 & $\begin{array}{l}\text { Banyaknya siswa yang } \\
\text { belum tuntas }\end{array}$ & $\begin{array}{c}9 \\
\text { orang }\end{array}$ & 6 orang \\
\hline 5 & Ketuntasan Klasikal & $72,73 \%$ & $81,51 \%$ \\
\hline 6 & Daya Serap Klasikal & $71,81 \%$ & $81,81 \%$ \\
\hline
\end{tabular}

Dari Tabel 1 dapat dilihat bahwa pada siklus I hasil belajar siswa belum mencapai standar ketuntasannya yakni masih berada di bawah 80 $\%$, oleh karena itu peneliti melakukan refleksi untuk meninjau kembali hal-hal yang perlu diperbaiki agar kelemahan atau kekurangan disiklus I dapat diminimalisir dan dapat meningkatkan hasil belajar siswa pada siklus II. Dan pada siklus II sudah mengalami peningkatan, dan ketuntasan klasikalnya sebesar $81,51 \%$.

Adapun kelemahan yang terjadi pada siklus I yaitu, siswa masih belum bisa menguji hipotesis, merumuskan kesimpulan dan menyimpulkan kesimpulan. Hal ini disebabkan guru (peneliti) belum bisa memberikan arahan dan penjelasan secara keseluruhan kepada siswa pada saat proses kegiatan belajar mengajar dan praktikum/eksperimen. Untuk itu guru (peneliti) harus bisa memberikan arahan dan penjelasan secara keseluruhan kepada siswa pada saat disiklus II.

Setelah melakukan refleksi, peneliti kemudian melaksanakan rekomendasi perbaikan untuk mengatasi dan meminimalisir 
kelemahan yang ada sehingga aktivitas guru dan siswa mengalami peningkatan, hasil belajar siswa juga di harapkan mengalami peningkatan.

Adapun grafik peningkatan ketuntasan siklus I dan II dapat dilihat pada Gambar 2.

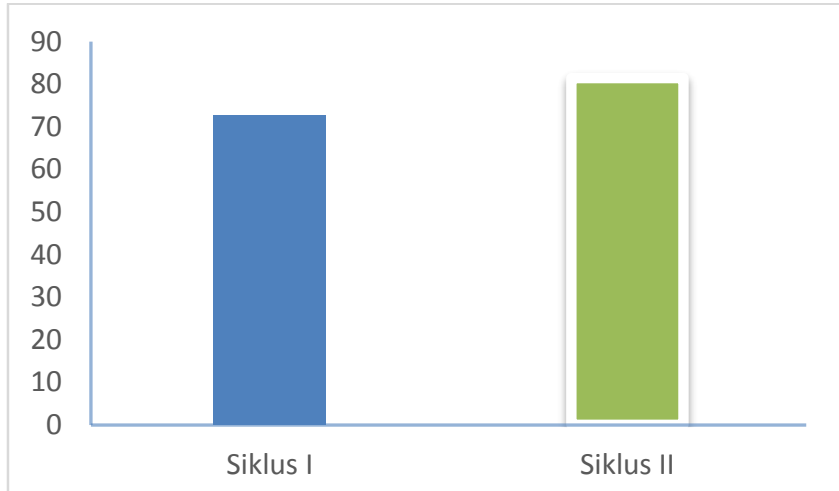

Gbr 2. Grafik Peningkatan Ketuntasan Klasikal Siklus I dan Siklus II.

Dari Gambar 4 dapat dilihat bahwa persentase hasil belajar dari siklus I ke siklus II mengalami peningkatan hal ini terjadi karena kelemahan pada siklus I telah di perbaiki sehingga dapat meningkatkan aktivitas guru dan siswa serta hasil belajar siswa.

Dengan adanya refleksi tindakan dimana peneliti menganalisis kekurangan dari siklus I dan merekomendasikan kekurangan tersebut untuk diperbaiki pada siklus II, sehingga pada siklus II terjadi peningkatan hasil belajar yang sudah memenuhi standar indikator keberhasilan. Hal ini dikarenakan faktor-faktor penyebab kegagalan pada siklus I telah berhasil diminimalisir.

Pada setiap tahap pembelajaran peran guru sangat berpengaruh terhadap peningkatan aktivitas siswa. Pada siklus I aktivitas guru sudah berada dalam kategori baik meskipun demikian guru berusaha untuk lebih meningkatkan aktivitasnya sehingga pada siklus II berada pada kategori sangat baik. Guru berusaha memperhatikan masalahmasalah yang dihadapi oleh siswa pada saat melaksanakan pembelajaran dan berusaha mendorong siswa agar mampu mengungkapkan ide atau gagasan mereka dan membangun konsep sendiri melalui pembelajaran. Guru juga berusaha memotivasi siswa agar lebih aktif dalam mencari dan memahami materi yang diajarkan.

Berdasarkan hasil yang diperoleh pada penelitian ini maka dapat dikatakan bahwa penerapan model pembelajaran Inquiry berbantuan video pembelajaran dan tutorial dapat meningkatkan hasil belajar fisika pada siswa kelas X SMAN 5 Palu.

Hasil penelitian ini menunjukkan hasil yang sama dengan penelitian sebelumnya [4], bahwa penggunaan video pembelajaran dapat meningkatkan minat dan hasil belajar siswa.

\section{KESIMPULAN DAN SARAN}

Berdasarkan hasil analisis data yang diperoleh dalam penelitian ini, maka dapat disimpulkan bahwa penerapan model pembelajaran Inquiry berbantuan Video Pembelajaran dan Tutorial dapat meningkatkan hasil belajar fisika siswa pada kelas X MIPA SMA Negeri 5 Palu. Hal ini ditunjukkan dengan adanya peningkatan hasil belajar siswa dari siklus I ke siklus II.Ketuntasan belajar klasikal pada siklus I sebesar $72,73 \%$ dan pada siklus II meningkat menjadi $81,51 \%$. Serta aktivitas siswa dan guru pada siklus I berada pada kategori baik, dan Pada siklus II berada pada kategori sangat baik.

Berdasarkan hasil penelitian dan analisis data serta kesimpulan, maka peneliti menyarankan agar: (1) pengelolaan waktu perlu dipertimbangkan dalam setiap pembelajaran, sehingga semua aktivitas siswa diharapkan dapat dikembangkan sesuai tujuan pembelajaran, (2) penerapan model pembelajaran Inquiry berbantuan Video Pembelajaran dan Tutorial cukup efektif dalam meningkatkan aktifitas serta hasil belajar siswa. Model ini juga dapat dijadikan alternatif dalam proses pembelajaran untuk pokok bahasan yang lain.

\section{DAFTAR PUSTAKA}

[1] R. A. Djana, A. Rede, dan M. Pasaribu. (2013). "Meningkatkan Hasil Belajar Siswa di SD Negeri 20 Ampana pada Pembelajaran IPA melalui Metode". Inquiry Jurnal Kreatif Tadulako Online, Vol. 1 No. 2, 32-39.

[2] Nurhani, Y. K. Paluin., dan D. Tureni. (2016). "Penerapan Metode Inquiry Dalam Meningkatkan Hasil Belajar Siswa Pada Mata Pelajaran IPA di Kelas IV SDN 3 Siwalempu" Jurnal Kreatif Tadulako Online, Vol. 4 No. 2, 90-105.

[3] Busyaeri, Udin, dan A. Zaenuddin. (2016). Pengaruh Penggunaan Video Pembelajaran Terhadap Peningkatan Hasil Belajar Mapel IPA Di MIN Kroya Cirebon. Jurnal Skripsi. Jurusan PGMI FITK IAIN Syekh Nurjati Cirebon. Vol 3 (3), 12Halaman.

[4] Sunendar, Tatang. (2008). Penelitian Tindakan Kelas Part II. Lembaga Penjaminan Mutu Pendidikan. Tersedia: www.wordpress.com. [20 Agustus 2017]. 